\section{In Vitro Cultivation of Mouse Ascites Tumour Cells for Virus-Host Cell Studies}

$\mathrm{K}_{\text {IEIN }}{ }^{1,2}$ has found that the so-called Ehrlich ascites tumours of mice offer several advantrges over solid tumours for studying the effect of a substance on the growth-rate, on nucleic acid content and on the cytomorphology of neoplastic cells. These advantages have been applied lately by a number of investigators $^{3,4}$ to studies dealing with the effect of viral infection upon the neoplastic process and with the adaptation of virus to the ascitic cells ${ }^{5}$ These investigations have all been carried out in the peritoneal cavity of the mouse. An in vitro technique which may prove feasible for similar studies, par. ticularly host-cell virus studies in neoplastic cells cultivated apart from the animal, was recently developed in our laboratory.

Ascites cell suspensions were freshly removed from tumorous Webster-strain white mice, centrifuged at 2,000 r.p.m. for $15 \mathrm{~min}$. and the supernatant decanted. The cells were then resuspended in a nutrient medium composed of 50 per cent ox serum ultrafiltrate, 10 per cent chick-embryo extract and 40 per cent Hanks's belanced selt solution with 0.002 per cent phenol red indicetor. Two hundred units of penicillin and $100 \mu \mathrm{gm}$. of streptomycin were added at first to preclude contamination. 1-c.c. aliquots were dispensed into Porter flasks in which were incorporated glass coverslips (11 mm. $\times 22 \mathrm{~mm}$.) and the flasks incubated at $36^{\circ} \mathrm{C}$. The medium was renewed daily for the first four or five days, the $p \mathrm{H}$ during this period showing diminutions from the 7.5 of the fresh medium to 6.6-6.8 within twenty-four hours. The fluid phase in the first twenty-four hours turned a chocolatebrown, due most likely to denaturation of hæmoglobin from red blood cells carried over with the ascitic fluid. Thereafter, the medium was renewed at weekly intervals for six weeks. Coverslips were withdrawn from random Porter flasks at the time of fluid renewal and stained by the May-Grünwald and Giemsa method'.

Microscopic examination of the stained coverslips indicated that the ascites tumour cells maintained their usual appearance for at least the first week of culture. In the following weeks increasing numbers of cells showed progressive degeneration as manifested by increasing cytoplasmic vacuolation and karyoplasmic fragmentation. However, by the end of the sixth week there were still a considerable number of cells presenting a normal appearance. In this connexion, it should be mentioned that Hull? ${ }^{\text {, employing }}$ a subculture technique, has succeeded in serially culturing a line of ascites tumour cells for more than eight months. The frequency of blood cells and wandering cells was of the order of only a few per cent and these were readily distinguishable.

The utilization of cells morphologically, functionally, and potentially alike would permit a far more exact evaluation of host-cell reactions with, and responses to, specific viruses under conditions of culture. The Ehrlich ascites tumour cells being maximally dedifferentiated ${ }^{8}$ do not manifest the protean ensemble of morphological forms so frequently observed with cells in culture, a phenomenon ascribed by Weiss' to 'modulations'. In addition to the advantage of uniform cells, which is ordinarily provided only by continuous cultures maintained over long periods of time, the absence of a fibrin clot affords the cells a maximum exposure to the viral particles in the fluid phase. Also, the ready manipula- tion and staining of the coverslips upon which the cultures grow permit a sequential study of cytomorphological development and change.

This investigation was aided by a fellowship from the National Foundation for Infantile Paralysis.

BenJamin V. Sieget

Department of Pharmacology and Therapeutics,

Stanford University School of Medicine, San Francisco 15.

Nov. 20.

1 Klein, G., Cancer, 3, 1052 (1950).

${ }^{2}$ Klein, G., Exp. Cell Res., 2, 518 (1951).

${ }^{3}$ Koprowska, I., and Koprowski, H., Fed. Proc., 11, 420 (1952).

4 Love, R., and Koprowski, H., Fed. Proc., 11, 421 (1952).

${ }^{5}$ Ackermann, W. W., and Kurtz, H., Proc. Soc. Exp. Biol. and Med., 81, 421 (1952).

- Jacobson, W., and Webb, M., Exp. Cell Res., 3, 163 (1952).

"Hull, R. M., Science, 117, 223 (1953).

${ }^{8}$ Dietrich, A., and Schutzinger, L., Z. Krebs., 56, 121 (1948).

'Weiss, P., "Principles_of Development" (Henry Holt and Co., New York, 1939).

\section{Vaccination against Hæmorrhagic Septicæmia of Bovines}

HAEMORRHAGIC septicæmia kills many thousands of cattle and buffaloes in Asia each year. Vaccination with conventional products such as formalin-killed cultures of Pasteurella multocida have not been considered an effective form of prophylaxis although practised for the past thirty years or so. The serological typing of strains of the causative organism and studies on its antigenic structure have not been pursued extensively in Asiatic countries in the past. In recent studies sponsored by the Food and Agriculture Organization of the United Nations, strains of $P$. multocida recovered from field cases of the disesse in south-east Asia were typed by the mouse protection method of Roberts ${ }^{1}$; 14 Burmese, 3 Indian, 2 Pakistanian, 2 Mrlayan, 2 Siamese and one Indonesian strains were found to be type I. Only one other serotype was recovered from bovines-a single strain of type IV from Burma.

P. multocida type $I$ is a small-capsule variety of pasteurella which, unlike the large-capsule varieties, is not decapsulated by bull testis hyaluronidase. During the first and second subcultivations after primary isolation, type I strains are agglutinable only by low dilutions of homologous antisera, but in subsequent subcultivations agglutinability. is increased by up to a hundredfold without any obvious change in morphology. At the same time, agglutinability of cells in cetyl trimethyl ammonium bromide declines. These facts suggest that type I strains may have an antigen analogous to the ' $\mathrm{Vi}$ ' of Salmonella typhosa. Cultures relatively inagglutinable in homologous antisera have been provisionally called 'phase I' cultures and are used for vaccine production. Simple formalin-killed bacterins made from 'phase I' cultures have not been highly successful as prophylactic agents, only 1 of 11 and 11 of 16 bovines having been protected against a 25,000 lethal dose challenge four weeks after inoculation. However, when an equivalent dose of 'phase I' cells, formalin-killed, was incorporated in a mineral oil-lanolin emulsion and injected intramuscularly in a dose of $2 \mathrm{ml}$. the results were greatly improved. In a series of small experiments in Burma and Siam a total of 36 of 39 cattle and buffaloes were protected against 25,000200,000 lethal doses injected subcutaneously four to five weeks after inoculation with adjuvant 'phase I' 